\title{
The Allelopathic Effects of Lantana camara on Seed Germination and Growth of Selected Bioassay Species
}

\author{
Senarathne, S. H. S. ${ }^{1 *}$, R. D. V. Fernando ${ }^{2}$ and U. R. Sangakkara ${ }^{2}$
}

\begin{abstract}
The allelopathic effects of Lantana camara L. (Family : Verbenaceae) on germination and seedling establishment of some agricultural crops and weed species have been identified. Aqueous extracts of dry leaves and contaminated soil where $L$. camara is grown were used to verify allelopathic effect on seed germination of five bioassay species; Raphanus sativas, Capsicum annum, Lycopersicum esculantem, Crotalaria juncia and Chromoleana odorata. Fifty seeds from each bioassay species were placed in a petri dish containing leaf extracts or contaminated soil, and seed germination were examined after 3 days. The plant house experiments were carried out to evaluate the impact of L. camara contaminated soil and leaf debris using $L$. esculantem as the indicator plant. Seed germination of $L$. esculentem, C. junica and Capsicum annum was significantly inhibited by L. camara contaminated soil. However, the degree of inhibition varied among the bioassay species. The aqueous extract of dry leaves of $L$. camara was highly phytotoxic and it significantly reduced seed germination of all bioassay species. There was a decline in plant height, leaf area and shoot dry weight of tomato only in early growth stages when grown in L. camara contaminated soils. However, incorporation of leaf debris into soil affected the vegetative growth of tomato in early stages when the leaf debris concentration was increased. Growth recovered at the latter part of the life cycle. On the basis of these results it can be concluded that the allelochemicals in $L$. camara contaminated soils are harmful to the seed germination of crop species. The adverse effect was present only during the early growth stages and it did not suppress the latter part of the plant growth. These responses are attributed to allelopathic effects which need confirmation under field conditions.
\end{abstract}

Key words: allelopathy; germination; Lantana camara; weed seed.

\footnotetext{
${ }^{1}$ Agronomy Division, Coconut Research Institute, Lunuwila 61150, Sri Lanka.

${ }^{2}$ Faculty of Agriculture, University of Peradeniya, Peradeniya, Sri Lanka.

* Corresponding author : Phone)+94-77-9351163, Fax)+94-31-2257391, E-mail) shsumith71@yahoo.com
}

(Received August 24, 2011; Revised September 6, 2011; Accepted September 10, 2011) 


\section{INTRODUCTION}

Allelopathy is the negative effect of chemicals released by one plant species on the growth or reproduction of another plant species (Weidenhamer et al. 1989; Schenk et al. 1999; Callaway and Aschehoug, 2000). Allelopathy also is described as interference in the growth of neighboring plants or microorganisms by allelochemicals that are released through volatilization, eluviations and decomposition of the plant or root exudates during growth (Rice 1984; Putman and Tang 1986). Allelochemicals also can indirectly affect plants through the inhibition of microorganisms, including nitrogen fixing and nitrifying bacteria (Rice 1964), and ectomycorrhizae (Walker et al. 1999). Allelopathy widely exists in nature and plays a vital role in crop cultivation systems, controlling weeds, preventing crops from disease and insect infection.

L. camara L. (Family: Verbenaceae) is considered as an invasive woody shrub, and is found throughout Sri Lanka. Its toxic properties against cattle, small ruminants (Ghisalberti 2000), spores of liverwort Aserella angusta (Kothari and Chaudhary 2001), cyanophyte Microcystis aerugina (Kong et al. 2006), antimicrobial activity on Bacillus subtillis has been well documented (Loset et al. 2000; Misra and Laatsch 2000). Further, the toxic effects brought out by allelopathy of Lantana on root growth of soya bean and wheat have also been reported (Oudhia 2000; Oudhia and Tripathi 2000). On the other hand, some beneficial effects of $L$. camara have also been recognized. It is used, either along or together with other plants such as Croton lacciferus as mulch in paddy fields in the conventional agricultural practices for pest control. Allelochemicals of Lantana are composed of Lantadene A and Lantadene B, volatile oils such as caryophyllene, cieol and pinene (Kong et al. 2006; Abdel-Hady et al. 2005). However, its effect on weeds has not been reported.

The present study was undertaken to determine the alleopathic activity of $L$. camara on seed germination of selected bioassay species. The study focused on some important vegetables and weed species, namely $L$. esculentum, Raphanus sativas, C. annum, C. junica and Chromoleana odorata, which are a noxious weeds in coconut plantations. The aim of the study was to identify the impact of Lantana on germination of selected weed and crop species and seedling growth of $L$. esculentum.

\section{MATERIALS AND METHODS}

The experiments were carried out in the plant house of the Coconut Research Institute located in the Low country Intermediate Zone of the North Western province of Sri Lanka from March to August 2007. In the plant house, the photo-synthetically active radiation (PAR) ranged between $500 \sim 1,150 \mu \mathrm{mol} \mathrm{m}^{-2} \mathrm{~s}^{-1}$ and the average day and night temperatures were in the range of $30 \sim 34$ ${ }^{\circ} \mathrm{C}$ and $26 \sim 30^{\circ} \mathrm{C}$, respectively. Relative humidity varied between $35 \sim 60 \%$ during the day and $20 \sim 27 \%$ during the night. In the bioassay, $R$ sativas, $C$. annum, $L$. esculentem, $C$. junica and $C$. odorata seeds were used as the test species due to their high sensitivity to the phytotoxic activity of $L$. camara as observed in a preliminary study. Seeds of the selected weed species namely $C$. odorata and $C$. junica were collected from five different locations in the major coconut growing regions of Sri Lanka between in March 2007 and were stored at $5^{\circ} \mathrm{C}$ under dark conditions. Seeds of radish $(R$. sativa), chillie (C. annum), and tomato (L. esculentem) were taken from the Seed and Plant Material Development Centre, Department of Agriculture, Sri Lanka. The selected treatments of the experiments were arranged in a Complete Randomized Design (CRD) with ten replicates (each Petri dish and pot representing one replication of a single species in each trial) in the respective studies.

\section{Effect of residual toxicity of contaminated soil on seed germination of bioassay species}

Contaminated soil (top soil obtained from an area covered by a well grown canopy of Lantana plants 
continuously for 5 years) was collected to a depth of $5 \mathrm{~cm}$. Soil from a field that did not have Lantana camara was used as a control. These soils were of the same soil group with similar chemical and physical properties. Soil was classified as Madampe soil series (light textured high productive soil series; bulk density = $1.48 \pm 0.02 \mathrm{~g} \mathrm{~cm}^{-3}$; total available water $=5.71 \pm 0.89 \%$; penetrometer resistance $=240 \pm 16.3 \mathrm{~N} \mathrm{~cm}^{-2}$ ) was located in Bandirippuwa Estate, Lunuwila in the low country Intermediate climate zone $\left(08^{\circ} 02 \mathrm{~N}, 79^{\circ} \mathrm{E}, 35 \mathrm{~m}\right.$ altitude) (Senarathne et al. 2010).

The two soils were dried at room temperature and sieved through a $2 \mathrm{~mm}$ mesh. Ten grams of test and control soils were uniformly spread on separate $9 \mathrm{~cm}$ diameter petri dishes, fifty seeds of the bioassay species were placed uniformly on these soils and covered with the same soil. Soil was adequately moistened with distilled water. The dishes were kept in plant house at $27 \sim 30^{\circ} \mathrm{C}$. Each treatment was replicated ten times.

\section{Effect of aqueous extracts of dry leaves on seed germination of bioassay species}

Dry leaves of $L$. camara were cut into small pieces, dried under full sunlight for 1 week and ground to a powder with an electrical grinder (Thomas Wiley, Thomas Company, U.S.A). The dried powdered leaves were immersed in distilled water in the ratio of $1: 20$ $\mathrm{w} / \mathrm{v}$ and agitated for 24 hours on an orbital shaker at room temperature $\left(29^{\circ} \mathrm{C}\right)$. The extract was strained through two layers of filter paper (Whatmans No. 02). The extract was refrigerated at $5^{\circ} \mathrm{C}$ until use. One concentration of the dry leaf aqueous extract was used in this experiment. Fifty seeds each of selected bioassay species were placed separately in $9 \mathrm{~cm}$ diameter petri dishes lined with cotton wool and $5 \mathrm{ml}$ volumes of the leaf extracts was added per dish, distilled water was used for the control. The perti dishes were kept in a plant house for 72 hours at $28 \sim 30^{\circ} \mathrm{C}$. Treatments were replicated ten times.
Effect of residual toxicity of contaminated soil on growth of Lycopersicum esculentem

Soils obtained from Lantana grown and Lantana free fields were dried at room temperature and sieved through a $2 \mathrm{~mm}$ mesh. Uniform three weeks old tomato seedlings were transplanted in polythene bags $(28 \mathrm{~cm}$ diameter, $40 \mathrm{~cm}$ height and 500 gauges) filled with either of the two soils, to determine the impact of Lantana contaminated soil on growth and yield of tomato. Each treatment had 16 replicates and one polythene bag was referred to as a replicate.

\section{Effect of Lantana debris on growth of Lycopersicum esculentem}

Mature Lantana leaves were collected from a coconut estates and air dried for one week. The dried leaves were grounded using a laboratory mill (Thomas-wiley, Thomas Company, U.S.A.) and kept in a refrigerator until use.

The soil was prepared by mixing four rates of Lantana leaves as given below

$$
\begin{aligned}
& \mathrm{T}_{1}-0 \mathrm{~g} \text { of leaf debris } / \mathrm{kg} \text { soil (control) } \\
& \mathrm{T}_{2}-10 \mathrm{~g} \text { of leaf debris } / \mathrm{kg} \text { soil } \\
& \mathrm{T}_{3}-20 \mathrm{~g} \text { of leaf debris } / \mathrm{kg} \text { soil } \\
& \mathrm{T}_{4}-30 \mathrm{~g} \text { of leaf debris } / \mathrm{kg} \text { soil }
\end{aligned}
$$

Uniform three weeks old tomato seedlings were transplanted in separate polythene bags $(28 \mathrm{~cm}$ diameter and $40 \mathrm{~cm}$ height and 500 gauges) filled with these prepared soils to determine the impact of Lantana leaf debris on growth and yield of tomato. Sixteen replicates of each treatment were used, where one polythene bag was a replicate.

\section{Data collection}

Germination of $R$. sativas, $C$. annum, L. esculentem, $C$. junica and $C$. odorata were recorded daily for 12 days according to the method of the Association of Official Seed Analysis (1985) to determine the germination percentage using the following formula. 
Germination $\%=\frac{\text { No of Germinated seeds }}{\text { Total no of seeds }} * 100$

\section{Statistical analysis}

An Analysis of Variance (ANOVA) using Statistical software SAS was carried out and the significance was tested using Least Significant Differences (LSD) at 5\% probability $(<$ B31 $>$ SAS Institute $1999</ C>)$.

\section{RESULTS AND DICUSSION}

\section{Residual toxicity of contaminated soil on seed germination of selected bioassay species}

Seed germination of bioassay species in soil from the field with Lantana for 5 years was lower than those in the soil from the area without Lantana (Table 1). These demonstrated that soil collected from the L. camara rhizosphere had a strong inhibitory effect on the seed germination of L. esculentem, $C$. junica and C. annum. However, there was no significant difference of the allelopathic effect of $L$. camara on $R$. sativas and $C$. odorata seeds. The lowest germination percentage (17\%) was recorded in C. junica seeds, when those seeds were sown on the L. camara contaminated soil, while the highest germination percentage was found in $R$. sativas (69\%) seeds when grown in the same soil (Table1). This is in agreement with the results of Chung and Miller (1995) who reported the inhibitory effect of soil collected from the surrounding area of alfalfa plants on their test bioassay species. This inhibition may be due to the release of phytotoxic substances by the root itself or through interaction between microorganisms and tissue litter.

However, this interpretation needs further study because several factors are involved in allelopathic activity and seed germination. In addition, the alteration of the physico-chemicals characteristics of the soil may affect the quantitative and qualitative of phyto-chemicals, which, in turn influences the allelopathic expression of plants (De Moral and Muller 1970). However, Achhireddy and Singh (1984) reported that soil collected under Lantana had no effect on germination and growth of milkweed (Asclepias syriaca) vine. However, in our experiment $L$. camara contaminated soil inhibited germination of the above species to a greater extent than the control treatment.

\section{Effect of aqueous extracts of dry leaves on seed germination of selected bioassay species}

Application of $L$. camara dried leaf extract significantly reduced the seed germination and the lowest germination percentages (7\% and 13\%) were found in C. juncia and $C$. odorata, while the highest germination percentage (34\%) was found in C. annum seeds (Table 2).

These results are supported by the findings of Helgeson and Konzak (1950) where aqueous extracts of field bindweed (Convolvulus arvensis) and Canada thistle (Crisium arvense) inhibited the germination of seeds and growth of seedlings of many crops. Overall results

Table 1. Effect of residual toxicity of contaminated soil on seed germination of selected bioassay species.

\begin{tabular}{cccccc}
\hline \multirow{2}{*}{ Treatment } & \multicolumn{5}{c}{ Seed germination $\%$} \\
\cline { 2 - 6 } & $\begin{array}{c}\text { Raphanus } \\
\text { sativas }\end{array}$ & $\begin{array}{c}\text { Lycopersicum } \\
\text { esculentem }\end{array}$ & $\begin{array}{c}\text { Capsicum } \\
\text { annum }\end{array}$ & $\begin{array}{c}\text { Crotalaria } \\
\text { junica }\end{array}$ & $\begin{array}{c}\text { Chromoleana } \\
\text { odorata }\end{array}$ \\
\hline $\mathrm{T}_{1}$ Control & 76 & 78 & 89 & 58 & 42 \\
$\mathrm{~T}_{2}$ Lantana camara & 69 & 42 & 35 & 17 & 38 \\
Significance & $\mathrm{ns}$ & $* *$ & $* *$ & $*$ & $\mathrm{~ns}$ \\
LSD (P = 0.05) & - & 26.5 & 24.4 & 29.5 & \\
\hline
\end{tabular}

*Significant ${ }^{* *}$ Highly Significant. 
Table 2. Effect of dried leaf extract on seed germination of selected bioassay species.

\begin{tabular}{|c|c|c|c|c|c|}
\hline \multirow[b]{2}{*}{ Treatment } & \multicolumn{5}{|c|}{ Seed germination $\%$} \\
\hline & $\begin{array}{l}\text { Raphanus } \\
\text { sativas }\end{array}$ & $\begin{array}{c}\text { Lycopersicum } \\
\text { esculentem }\end{array}$ & $\begin{array}{c}\text { Capsicum } \\
\text { annum }\end{array}$ & $\begin{array}{l}\text { Crotalaria } \\
\text { junica }\end{array}$ & $\begin{array}{c}\text { Chromoleana } \\
\text { odorata }\end{array}$ \\
\hline $\mathrm{T}_{1}$ Control & 95 & 72 & 68 & 35 & 56 \\
\hline $\mathrm{T}_{2}$ L. camara & 22 & 29 & 34 & 7 & 13 \\
\hline Significance & $* *$ & $* *$ & $* *$ & $* *$ & $*$ \\
\hline LSD $(P=0.05)$ & 31.8 & 30.4 & 11.2 & 11.3 & 16.7 \\
\hline
\end{tabular}

*Significant **Highly Significant.

suggested that allelopathic effect of dried leaves extract of L. camara significantly $(\mathrm{P} \geq 0.05)$ suppressed the seed germination of all the bioassay species seeds.

\section{Effect of residual toxicity of contaminated soil on growth of Lycopersicum esculentem}

The seedling height, leaf area and shoot dry weight of tomato plants increased with time, irrespective of the soil type (Fig. 1, 2 and 3). However, the shoot growth of plants grown on the Lantana contaminated soil was significantly reduced up to $6^{\text {th }}$ week after planting when compared to that of plants grown in non-contaminated soil. At the latter part of the vegetative growth period there were no significant differences.

This clearly implies an allelopathic effect on the measured parameters only in the early vegetative growth period, due to the contamination of the soil by Lantana. Results reported here are contrary to those of

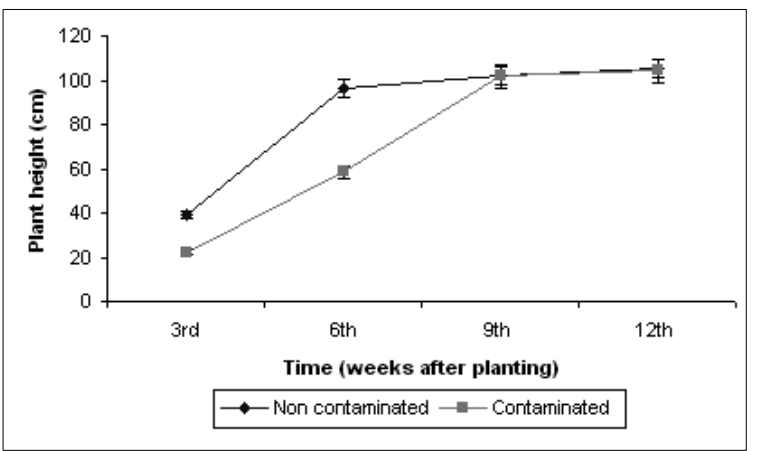

Fig. 1. Effect of Lantana-contaminated soil on plant height of Lycopersicum esculentem. The vertical bars indicate $\mathrm{SE}$ of the mean.

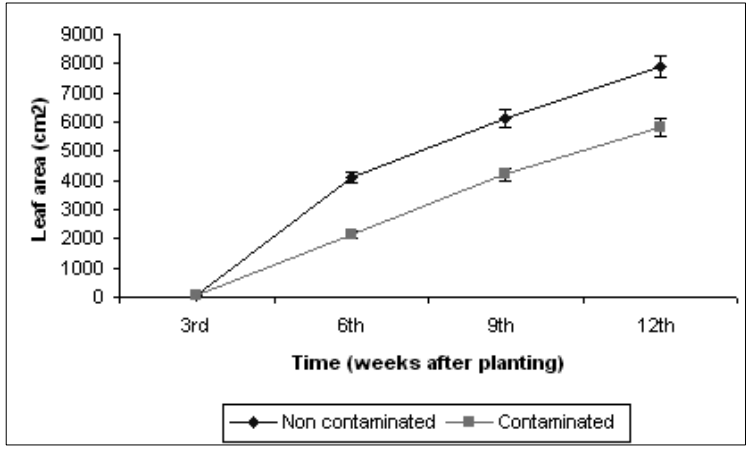

Fig. 2. Effect of Lantana-contaminated soil on leaf area of Lycopersicum esculentem. The vertical bars indicate $\mathrm{SE}$ of the mean.

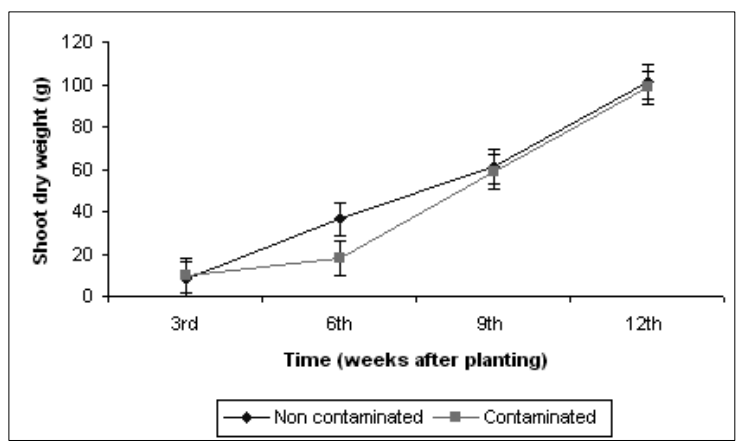

Fig. 3. Effect of Lantana-contaminated soil on shoot dry weight of Lycopersicum esculentem. The vertical bars indicate SE of the mean.

Achhireddy and Singh (1984) which indicated that soil collected under Lantana had no effect on germination and growth of milkweed vine. It should be noted that response to allelochemicals varies widely among species (Whittaker 1970).

(C) 2011 Korean Society of Weed Science 


\section{Effect of Lantana leaf debris on growth of Lycopersicum esculentem}

The effect of the Lantana camara leaf debris on the shoot growth of Lycopersicum esculentem seedlings in the soil incorporated with the debris was investigated because the tomato shoots were found to be the most sensitive in a preliminary study. The plant height of tomato plants increased with time in all four treatments, showing a typical sigmoid growth pattern. Generally, the application of leaf debris reduced plant height of tomato at early growth stages. The allelopathic effect emerged at the $3^{\text {rd }}$ week after planting and the effect was observed until the $9^{\text {th }}$ week after planting. The allelopathic impact was not present at the last sampling 12 weeks after planting (Fig. 4).

However, the leaf area of tomato plants grown in the control treatment was significantly decreased that of plants grown in other three treatments. The allelopathic

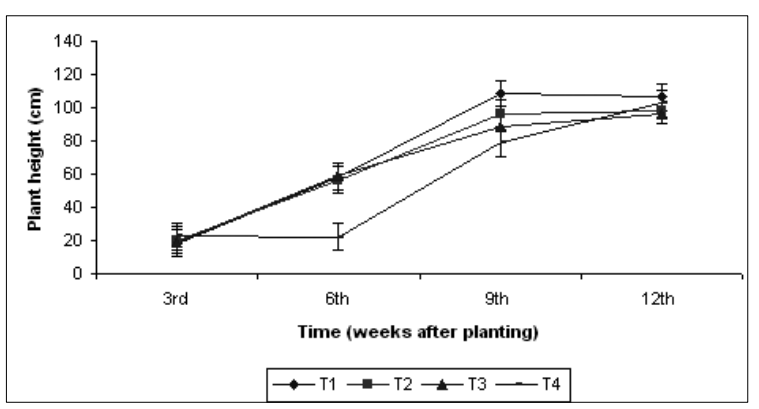

Fig. 4. Effect of Lantana camara leaf debris on plant height of Lycopersicum esculentem. The vertical bars indicate $\mathrm{SE}$ of the mean.

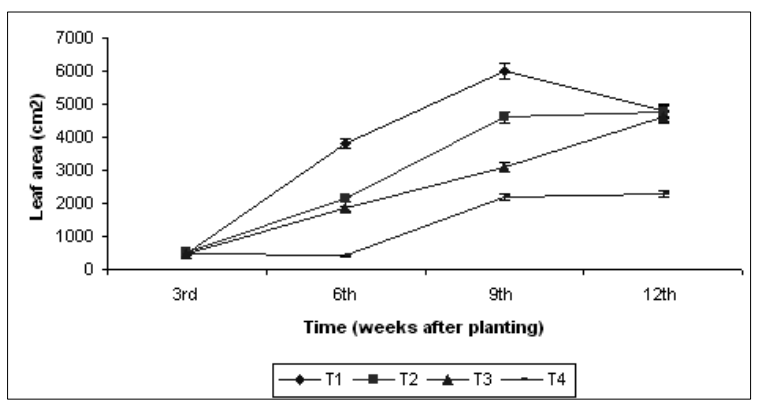

Fig. 5. Effect of Lantana camara leaf debris on plant leaf area of Lycopersicum esculentem. The vertical bars indicate SE of the mean.

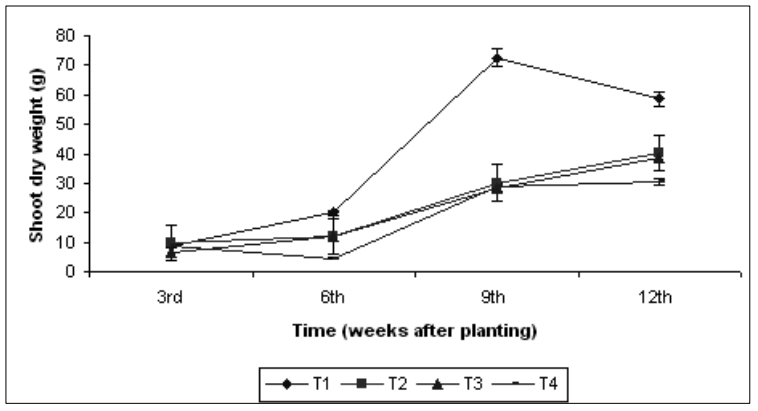

Vertical bars indicate \pm SE of the mean

Fig. 6. Effect of Lantana camara leaf debris on plant shoot dry weight of Lycopersicum esculentem. The vertical bars indicate $\mathrm{SE}$ of the mean.

effect was observed due to the leaf debris only up to $9^{\text {th }}$ week after planting (Fig. 5).

The shoot dry weight of tomato plants increased with time, irrespective of the treatments (Fig. 6). However, the significant effect of treatments on shoot dry weight was observed during the growth period of tomato plants. The mean shoot dry weight of $T_{1}$ in tomato was significantly higher than that in the other treatments. The allelopathic effect of Lantana leaf debris was observed up to the $9^{\text {th }}$ week. These results suggest that Lantana plant materials have phototoxic activity because it is well known that the possible toxic substances are released directly and or indirectly from the plant debris after degradation in the soil, as was shown with Mexican sunflower (Tithonioa diversifolia) (Tongma et al. 1998). Test plants in the debris studies responded not only to amount of debris but also to change in debris location. Phytotoxicity was enhanced by soil incorporation of plant debris. Incorporation of debris into soil may promote its chemical and microbial decomposition accompanied by release of soluble organic constituents (Sahid and Sugau 1993).

\section{CONCLUSION}

The selected bioassay species were more sensitive to inhibitory effects of dry leaf extracts, plant debris and contaminated rhizosphere soil of $L$. camara. Hence, $L$. 
camara has a significant allelopathic potential and is likely to release allelopathic substances to the environment. However, the sensitivity to allelochemicals and extent of inhibition varied between species. The allelopathic effect of $L$. camara may be an important mechanism involved in invasive success of this plant. Under natural conditions, where a great number of interactions with other organisms occur, these allelopathic effects can enhance or restrain plant growth and species diversity. Field experiments must be carried out to test the effectiveness of the allelopathic potential of above grass species under natural conditions.

\section{REFEENCES}

Abdel-Hady, N. M., A. S. Abdei-Halim and A. M. Al-Ghadban. 2005. Chemical composition and insecticidal activity of the volatile oils of leaves and flowers of Lantana camara L. cultivated in Egypt. J. Egypt Soc Parasitol. 35:687-698.

Achhireddy, N. R., and M. Singh. 1984. Allelopathic effects of Lantana (Lantana camara) on milkweed vine (Morrenia odorata). Weed Sci. 32:757-761.

Callaway, R. M., and E. T. Achwhoug. 2000. Invasive plants versus their new and old neighbors : a mechanism for exotic invasion. Science 290:521523.

Chung, M., and D. A. Miller. 1995. Effects of alfalfa plant and soil extract on germination and growth of alfalfa. Agron. 87:762-767.

De Moral, R., and C. H. Muller. 1970. Allelopathic effects of Eucalyptus camaldulensis. Am. Midland Naturalis 83:254-282.

Ghisalberti, E. L. 2000. Lantana camara L. (Verbenaceae), Fitoterapia 71:467-486.

Helgeson, E. A., and R. Konzak. 1950. Phytotoxic effects of aqueous extracts of field bindweed and of Canada thistle. A preliminary report, N. Dak, agr. Expt. Sta. Bimo, Bul, 12:71-76.

International Seed Testing Association (ISTA). 1985.
International rules for seed testing. Seed Science and Technology 13:299-355.

Kong, C. H., P. Wang, C. X. Zhang, M. X. Zhang and F. Hu. 2006. Herbicidal potential of allelochemicals from Lantana camara against Eichhornia crassipes and the alga Microcystis aeruginosa. Weed Res. 46:290-295.

Kothari, M., and B. L. Chaudhary. 2001. Allelopathic effects of Lantana camara Linn. On spore germination of Asterella angusta Steph. A liveworth Indian Journal of Experimental Biology 39:1941198.

Loset, J. R., A. Marston, M. P. Gupta and K. Hostettmann. 2000. Antifungal and larvicidal cordiaquinones from the roots of Cordia curassavica. Photochemistry 53:613-617.

Misra, L., and H. Laatsch. 2000. Triterpenoilds, esstential oil and photo-oxidative 28-13-lactonization of oleanolic acid from Lantana camara. Photochemistry 54:969-974.

Oudhia, P. 2000. Allelopathic effect of Lantana camara L. on germination of soybean. Legume Research 22:273-274.

Oudhia, P., and R. S. Tripathi. 2000. Allelopathic effect of Lantana camara on wheat. Crop Res. 19:357360.

Putman, A. R., and C. S. Tang. 1986. The science of allelopahthy. John Wiley and Sons, New York.

Rice, E. L. 1964. Inhibition of nitrogen fixing and nitrifying bacteria by seed plants. Ecology 45:824837.

Rice, E. L. 1984. Allelopathy, $2^{\text {nd }}$ edn. Academic Press, New York.

[SAS] Statistical Analysis Systems. 1999. SAS 1, STAT Users Guide, Release, 7.00 Cary, NC: Statistical Analysis Systems Institute, 1028 p.

Sahid, I. B., and J. B. Sugau. 1993. Allelopathic effect of Lantana (Lantana camara) and sSim weed (Chromolaena odorata) on selected crops. Weed Sci. 41:303-308.

Schenk, H. J., R. M. Callaway and B. E. Mahall 1999. 
Spatial segregation : are plants territorial's. Adv. Ecol. Res.28:146-180.

Senarathne, S. H. S., D. N. M Dissanayake and L. P. Vidhana Arachchi. 2010. Allelopathic potential of Brachiaria brizantha and Brachiaria milliformis on seed germination of selected bioassy species. Pakistan Journal of Weed Science Research 16(2): 207-216.

Tongma, S., K. Kobayashi and K. Usui 1998. Allelopathic activity of Mexican sunflower (Tithonia diversifolia (Hemsl.) in soil. Weed Sci. 46:432-437.

Walker, J. F., J. T. Miller, S. Lei, E. Semones and B.
D. Nilsen 1999. Suppression of ectomycorrhizae on canopy tree seedling in Rhododendron maximum L. (Ericaceae) thickets in the southern appalachians. Mycorrhiza 9:49-56.

Weidenhamer, J. D., D. C. Hartnett and J. T. Romwo. 1989. Density dependent phytotoxicity : distinguishing resources competition and allelopathic interference in plants. J. Appl. Eco. 26:613-624.

Whittaker, R. H. 1970. The biochemical ecology of higher plants. pp.43-70. In E. Sondheimer and J. B. Simeone, eds. Chemical Ecology. Academic Press, New York, 142-148. 